\title{
Influence of Genetic polymorphism of IL-2 and IL-6 on susceptibility to Helicobacter pylori infection and prognosis of Gastroduodenal Diseases
}

\author{
Khairallah A.S Mohammed ${ }^{1}$, Methaq M. Neamah AL-Hilfi ${ }^{2}$, Naael H. Ali ${ }^{3}$, Ali Dawood AL- \\ Hilfi $^{4}$ \\ \{dr.kmohammed@stu.edu.iq ${ }^{1}$, meethaqnama@gmail.com ${ }^{2}$,nhali66@yahoo.com $\left.{ }^{3}\right\}$
}

\author{
Department of Medical Lab Technology, College of Health and Medical Technology, Southern \\ Technical University, Iraq ${ }^{1,2}$ \\ College of Medicine, University of Basra, Iraq ${ }^{3}$ \\ $\mathrm{Al}$-Sader Teaching Hospital, Basra, Iraq ${ }^{4}$
}

\begin{abstract}
We wanted to see if there is a link between IL-6 -174G/C and -572G/C, IL-2 $330 \mathrm{~T} / \mathrm{G}$ and $+114 \mathrm{~T} / \mathrm{G}$ to the aetiology of $\mathrm{H}$. pylori infections. In $24 \mathrm{H}$. pylori-positive patients ( 5 chronic gastritis, 17 peptic ulcer, 2 stomach cancer) and 13 healthy people, PCR, DNA sequencing, and the ELISA technique were employed to describe the IL-2 and IL-6 polymorphisms and evaluate their serum levels. The IL-6 -174GG genotype was shown to be the most common (75\%) among patients with high rate of getting gastric cancer (OR: $4.8, \mathrm{P}<0.05)$. A high prevalence of IL-6-572GG genotype (66.7\%) was observed among patients with a possible high rate of getting gastric cancer in subjects carrying GC genotype (OR: 2.7, P >0.05). IL-2 -330TT and +114TG genotypes were most frequent $(58.3 \%, 50 \%$ respectively) among patients, of gastric cancer in patients carrying IL-2-330GG (OR: 2.4) and IL-2+114TT genotype (OR: 2.26). The serum levels of ILs $-2 / 6$ were varied about genetic variation.
\end{abstract}

Keywords: Helicobacter pylori, interleukin 6, interleukin 2, polymorphism

\section{Introduction}

Helicobacter pylori is a common pathogenic agent linked to chronic gastritis, peptic ulcer disease, and gastric cancer. The virulence factors of $\mathrm{H}$. pylori and the host immune response are responsible for the development and prognosis of $\mathrm{H}$. pylori infections. Interleukin 2 (IL-2) and interleukin 6 (IL-6) are significant members of the host immune system that play a critical role in the pathophysiology of H. pylori-induced gastro-duodenal disorders [1, 2]. Variations in the genes encoding these cytokines may modify their production or interaction with $\mathrm{H}$. pylori virulence factors, resulting in the severity of inflammation and perhaps influencing immunopathology $[2,3]$. IL-2 is an immunoregulatory cytokine that plays a role in cellmediated immunity $[1,2]$. T cells make it when mitogens activate them, or when antigenpresenting cells interact with them [1]. IL-2 also functions as the growth factor of T-cell and modulates the immune response by influencing T-cell differentiation into Th1 and Th2 effector subsets. [1]. It aids in the recruitment and spread of inflammatory immunological responses, such as H. Pylori-associated gastro-duodenal illness [2]. IL-2 polymorphisms related to the 
growth of atrophic gastritis, peptic ulcers, and stomach cancer in numerous investigations [3]. In the IL-2 gene, two polymorphisms have been discovered: - 330T/G and $+114 \mathrm{~T} / \mathrm{G}$. The $330 \mathrm{~T} / \mathrm{G}$ polymorphism is found in the IL-2 gene's promoter region and related to high variety of inflammatory illnesses and malignancies [4].

Monocytes, lymphocytes, macrophages, endothelium, and intestinal epithelial cells, among other immune and non-immune cells, release IL-6, a multifunctional cytokine. It functions as a link between the innate and adaptive immune systems, increasing IFN production in $\mathrm{T}$ cells and increasing immunoglobulin release in activated B cells [5]. Interleukin-6 is a cytokine that can be either pro-inflammatory or anti-inflammatory. Its functions include triggering an immunological response, combating infection, and responding to specific microbial compounds, as well as regulating body temperature and driving muscular contraction [6]. IL-6 gene polymorphisms have been linked to $\mathrm{H}$. pylori-mediated gastroduodenal illness in several investigations [7, 8, 9]. Many SNPs were discovered in the IL-6 promoter's 5' flanking region, including $-174,-572,-1363,-597$, and +634 [2]. IL-6-174 and IL-6 -572 have been linked to H. pylori-mediated gastro-duodenal illness in other investigations [10]. The goal of this investigation was to see if there was a link between polymorphisms in the genes that encode IL2 and IL- 6 and the immunological response that resulted from such genetic changes and the development of $\mathrm{H}$. pylori-mediated illnesses.

\section{Materials and Methods}

\subsection{Study Population}

The study showed in the Endoscopy Unit of a specialist centre for the digestive system and liver at Al Sadr Teaching Hospital, Basra - Iraq on 24 patients with Gastro-duodenal Diseases (suspected H. pylori infection) and 13 healthy individuals. Appropriate consent was agreed with patients. All individuals were tested for $\mathrm{H}$. Pylori faecal antigen and the positive results were confirmed by rapid urease test (helicotechUT PLUS, Strong Biotech Corporation, Taiwan). The eligible patients had been confirmed to have H. pylori with chronic gastritis or peptic ulcer by clinical and endoscopic examinations, and histopathologically confirmed to have gastric cancer by endoscopic biopsy.

\subsection{Assessment of Serum IL-2 and IL-6 Levels}

Each participant had three millilitres of venous blood drawn and centrifuged at $4000 \mathrm{RPM}$ for 15 minutes to collect serum. IL-2 and IL-6 levels in the blood were assessed using enzymelinked immunosorbent assay (ELISA) kits (KOMA ELISA KIT, KOMABIOTECH, KORA, IL2 Lot No:42223, IL-6 Lot No:46223). The tests were carried out as directed by the manufacturer.

\subsection{DNA Extraction}


DNA purification kits (PROMIGA, USA) were used to separate genomic DNA from completely fresh blood collected in EDTA anticoagulant tubes for molecular research, according to the producer's directions.

\subsection{PCR Technique}

Using specified primers, the PCR technique was employed to amplify definite sections of IL6 and IL2 (Table 1). $2 \mu \mathrm{l}$ DNA, $1 \mu 1$ per primer, $12.5 \mu 1$ master mix , and 8.51 nuclease-free water made up the reaction mix. An initial denaturation stage of 5 minutes at $94 \mathrm{oC}$ was followed by 37 cycles of 30 seconds at $94^{\circ} \mathrm{C}$, a 45 -second annealing step at $58 \mathrm{oC}$ for primer $\mathrm{A}$ and $60^{\circ} \mathrm{C}$ for primer $\mathrm{B}$, and a 1 -minute extension step at $72^{\circ} \mathrm{C}$, followed by an 8 -minute final extension at $72^{\circ} \mathrm{C}$. Agarose gel electrophoresis was used to visualise the amplified products.

\subsection{DNA Sequencing}

$20 \mu \mathrm{l}$ of PCR product were sent for sequencing with appropriate primers according to business instructions (Macrogen firm, South Korea). Bio Edit [11] and Nucleotide search (https://blast.ncbi.nlm.nih.gov/Blast.cgi?PAGE TYPE=BlastSearc) were used to analyse and align the sequences retrieved.

Table 1. The primers utilised in this study.

\begin{tabular}{|c|c|c|c|c|c|}
\hline $\mathrm{IL}$ & Gene & Primer & Classification & Size bp & Reference \\
\hline \multirow[t]{4}{*}{$I L-2$} & \multirow[t]{2}{*}{$A(I L-2-330 T / G)$} & $A F$ & $\begin{array}{l}\text { 5'ATTCACATGTTCAGTGT } \\
\text { AGTTCT3' }\end{array}$ & \multirow[t]{2}{*}{130} & Song et al [4] \\
\hline & & $A R$ & $\begin{array}{l}5^{\prime} \\
\text { GTGATAGCTCTAATTCAT } \\
\text { GC3' }\end{array}$ & & \\
\hline & \multirow[t]{2}{*}{$B L-2+114 T / G)$} & $B F$ & $\begin{array}{l}5^{\prime} \\
\text { ATGTACAGGATGCAACTC } \\
C T 3^{\prime}\end{array}$ & \multirow[t]{2}{*}{261} & Song et al [4] \\
\hline & & $B R$ & $\begin{array}{l}5^{\prime} \\
\text { TGGTGAGTTTGGGATTCT } \\
\text { TG3 }\end{array}$ & & \\
\hline \multirow[t]{4}{*}{$I L-6$} & \multirow[t]{2}{*}{ A L-6-572 G/C) } & $\mathrm{AF}$ & $\begin{array}{l}\text { 5'CTCCTCTAAGTGGGCT } \\
\text { GAAG3' }\end{array}$ & \multirow[t]{2}{*}{$\begin{array}{l}212 \\
\mathrm{~B}\end{array}$} & Zhang et al. [10] \\
\hline & & AR & $\begin{array}{l}\text { 5'CAGCCTGGGATTATG } \\
\text { AAGAA3' }\end{array}$ & & \\
\hline & \multirow[t]{2}{*}{ B L-6-174 G/C) } & $\mathrm{BF}$ & $\begin{array}{l}\text { 5'TTGTCAAGACATGCCA } \\
\text { AAGTG3' }\end{array}$ & \multirow[t]{2}{*}{300} & Matos et al [12] \\
\hline & & BR & $\begin{array}{l}\text { 5'TCAGACATCTCCAGTC } \\
\text { CTATA3' }\end{array}$ & & \\
\hline
\end{tabular}

\subsection{Statistical Analysis}


The SPSS Version 25 software was considered to conduct the statistical limits $\mathrm{P} \leq 0.05$ that was regarded important in all tests, and the relevant $\mathrm{P}$-value was determined as an indication of significance. Odds ratios (OR) with a 95 percent confidence interval (CI) were calculated to investigate the association between cytokine gene polymorphisms and gastroduodenal diseases and $\mathrm{H}$. pylori infection.

\section{Results}

Polymorphisms in the IL- 6 and IL-2 genes are referred to by allelic and genotypic, as well as their blood levels in H. pylori-positive patients and healthy people, are shown in Tables 2 to 5. For the IL-6 -174 SNP, the typical sequencing results of IL-6 (300 BP) revealed three genotypes: GG, GC, and CC (figure 1). As shown in Table 2, the IL6 polymorphisms -174 GG genotype and $\mathrm{G}$ allele are the most frequent (75\%, OR: $4.8, \mathrm{P}<0.05$ and $84.5 \%$, OR: 2.6 respectively) among H. pylori-positive patients of a significant gastric cancer risk. The results of Table 3 show a high prevalence of IL-6-572 GG genotype (66.7\%) among patients of a possible gastric cancer in subjects carrying GC genotype (OR: 2.7, P >0.05). Tables 4 and 5 show that IL-2-330 TT and IL-2+114 TG genotypes are most frequent (58.3\%, 50\%, respectively) among patients, of similar risk in patients carrying IL-2-330 GG (OR: 2.4, p> 0.05) and IL-2+114 TT genotype (OR: 2.26, P>0.05). All the genotypes of IL -6 and IL -2 which presented a possible high risk in developing $\mathrm{H}$. pylori infections produced high serum levels of these cytokines as represented from Table 2 to 5 .
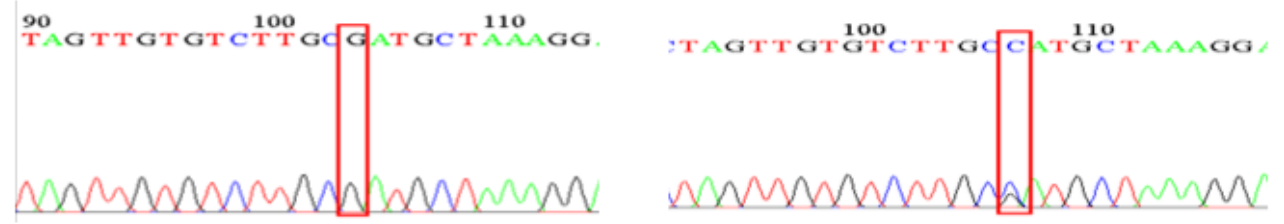

A- $\quad$ IL-6-174 GG

B - IL-6-174CG

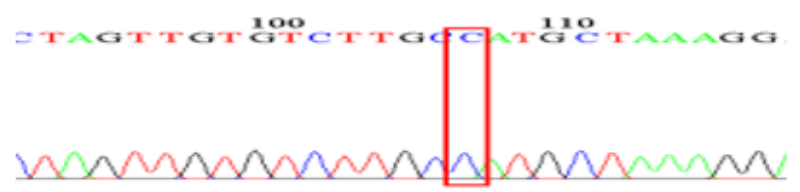

C - IL-6-174 CC

Fig 1. Sequencing results of IL-6 (300 BP) showing three genotypes for IL-6 -174 SNP.

\section{Discussion}

Human genetic variations are related to various illnesses [10]. The genotype at polymorphic regions in the gene encoding interleukins is hypothesised to determine their time variant that 
contributes to the growth of disorders in which interleukins have been involved. In normal subjects, the $\mathrm{G}$ allele at position -174 found to be related to amount of plasma IL- 6 than the C allele [13]. Other investigations have found that a high level of IL-6 is linked to gastric cancer and the tumor's development pattern [14]. Furthermore, a high level of IL-6 that was linked to angiogenesis in gastric carcinoma, as well as speeding up the activity and spread of cancer cells [15]. IL-6-174, -572 SNP has been linked to a variety of illnesses, breast cancer [16], irritable bowel syndrome [17], lung cancer [18], and prostate malignancies [19].

Table 2. Alleles and genotypes frequencies of IL-6-174 G>C and serum level of IL- 6 in the $H$. pylori-positive patients and healthy people.

\begin{tabular}{|c|c|c|c|c|c|c|c|c|c|}
\hline \multirow{3}{*}{\multicolumn{2}{|c|}{$\mathrm{IL}-6-174 \mathrm{G}>\mathrm{C}$}} & \multicolumn{3}{|c|}{ Patients versus healthy people } & \multicolumn{3}{|c|}{ Endoscopic findings } & \multirow{2}{*}{\multicolumn{2}{|c|}{$\begin{array}{l}\text { IL-6 serum level } \\
\text { Median } \\
(\mathrm{pg} / \mathrm{ml})\end{array}$}} \\
\hline & & \multirow{2}{*}{$\begin{array}{l}\begin{array}{l}\text { H. Pylori } \\
\text { patient } \\
(\mathrm{n}=24)\end{array} \\
\mathrm{N}(\%)\end{array}$} & \multirow{2}{*}{ 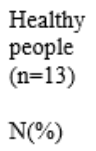 } & \multirow{2}{*}{$\begin{array}{l}\text { OR } \\
95 \% \text { CI } \\
\text { P-value }\end{array}$} & \multirow{2}{*}{$\begin{array}{l}\begin{array}{l}\text { Chronic } \\
\text { gastritis } \\
(\mathrm{n}=5)\end{array} \\
\mathrm{N}(\%)\end{array}$} & \multirow{2}{*}{$\begin{array}{l}\text { Peptic ulcer } \\
(\mathrm{n}=17) \\
\mathrm{N}(\%)\end{array}$} & \multirow{2}{*}{$\begin{array}{l}\text { Gastric } \\
\text { cancer } \\
(n=2) \\
N(\%)\end{array}$} & & \\
\hline & & & & & & & & Patients & $\begin{array}{l}\text { Healthy } \\
\text { people }\end{array}$ \\
\hline \multirow[t]{3}{*}{ Genotype } & $G G$ & $18(75)$ & $5(38.5)$ & $\begin{array}{l}4.8 \\
1.13-20.5 \\
0.034\end{array}$ & $3(60)$ & $13(76.5)$ & $2(100)$ & 169 & \multirow{5}{*}{10} \\
\hline & CG & $5(20.8)$ & $8(61.5)$ & $\begin{array}{l}0.16 \\
0.037-0.73 \\
0.017\end{array}$ & $2(40)$ & $3(17.6)$ & $0(0)$ & 112 & \\
\hline & $\mathrm{CC}$ & $1(4.2)$ & $0(0)$ & $\begin{array}{l}1.7 \\
0.062-45.3 \\
0.74\end{array}$ & $0(0)$ & $1(5.9)$ & $0(0)$ & 94 & \\
\hline \multirow[t]{2}{*}{ Allele } & $G$ & $41(85.4)$ & $18(69.2)$ & $\begin{array}{l}2.603 \\
0.82-8.3 \\
0.104\end{array}$ & & & & & \\
\hline & $\mathrm{C}$ & $7(14.6)$ & $8(30.8)$ & $\begin{array}{l}0.38 \\
0.12-1.22 \\
0.104\end{array}$ & & & & & \\
\hline
\end{tabular}


Table 3. Alleles and genotypes frequencies of IL-6-572 G>C and serum level of IL- 6 in the $H$. pylori-positive patients and healthy people.

\begin{tabular}{|c|c|c|c|c|c|c|c|c|c|}
\hline \multirow{3}{*}{\multicolumn{2}{|c|}{$\begin{array}{l}\text { IL-6- } \\
\quad 572 \mathrm{G}>\mathrm{C}\end{array}$}} & \multicolumn{3}{|c|}{ Patients versus healthy people } & \multicolumn{3}{|c|}{ Endoscopic findings } & \multirow{2}{*}{\multicolumn{2}{|c|}{$\begin{array}{c}\text { IL-6 serum level } \\
\text { Median } \\
(\mathrm{pg} / \mathrm{ml})\end{array}$}} \\
\hline & & \multirow{2}{*}{$\begin{array}{c}\begin{array}{c}\text { H. Pylori } \\
\text { patient } \\
(\mathrm{n}=24)\end{array} \\
\mathrm{N}(\%)\end{array}$} & \multirow{2}{*}{ 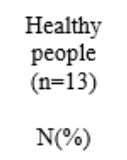 } & \multirow{2}{*}{$\begin{array}{c}\text { OR } \\
95 \% \mathrm{CI} \\
\text { P-value }\end{array}$} & \multirow{2}{*}{$\begin{array}{c}\text { Chronic } \\
\text { gastritis } \\
(\mathrm{n}=5) \\
\mathrm{N}(\%)\end{array}$} & \multirow{2}{*}{$\begin{array}{c}\begin{array}{c}\text { Peptic } \\
\text { ulcer } \\
(\mathrm{n}=17)\end{array} \\
\mathrm{N}(\%)\end{array}$} & \multirow{2}{*}{$\begin{array}{c}\text { Gastric cancer } \\
\qquad \begin{array}{c}(\mathrm{n}=2) \\
\mathrm{N}(\%)\end{array}\end{array}$} & & \\
\hline & & & & & & & & Patients & $\begin{array}{l}\text { Healthy } \\
\text { people }\end{array}$ \\
\hline \multirow[t]{3}{*}{ Genotype } & GG & $16(66.7)$ & $11(84.6 \%)$ & $\begin{array}{c}0.36 \\
0.065-2.05 \\
0.25\end{array}$ & $4(80)$ & $12(70.6)$ & $0(0)$ & 132 & \multirow{5}{*}{10} \\
\hline & GC & $8(33.3)$ & $2(15.4)$ & $\begin{array}{c}2.75 \\
0.49-15.5 \\
0.25\end{array}$ & $1(20)$ & $5(29.4)$ & $2(100)$ & 181 & \\
\hline & $\mathrm{CC}$ & ---- & -..- & -- & --- & -- & --- & -.- & \\
\hline \multirow[t]{2}{*}{ Allele } & G & $40(83.3)$ & $24(92.3)$ & $\begin{array}{l}0.42 \\
0.082-2.13 \\
0.29\end{array}$ & & & & & \\
\hline & $\mathrm{C}$ & $8(16.7)$ & $2(7.7)$ & $\begin{array}{l}2.4 \\
0.47-12.5 \\
0.29\end{array}$ & & & & & \\
\hline
\end{tabular}

Table 4. Alleles and genotypes frequencies of $\mathrm{IL}-2+114 \mathrm{~T}>\mathrm{G}$ and serum level of $\mathrm{IL}-2$ in the $H$. pylori-positive patients and healthy people.

\begin{tabular}{|c|c|c|c|c|c|c|c|c|c|}
\hline \multirow{3}{*}{\multicolumn{2}{|c|}{$\begin{array}{l}\mathrm{IL}-2+114 \\
\mathrm{~T}>\mathrm{G}\end{array}$}} & \multicolumn{3}{|c|}{ Patients versus healthy people } & \multicolumn{3}{|c|}{ Endoscopic findings } & \multirow{2}{*}{\multicolumn{2}{|c|}{$\begin{array}{l}\text { IL-2 serum level } \\
\text { Median } \\
(\mathrm{pg} / \mathrm{ml})\end{array}$}} \\
\hline & & \multirow{2}{*}{$\begin{array}{c}\begin{array}{c}\text { H. Pylori } \\
\text { patient } \\
(\mathrm{n}=24)\end{array} \\
\mathrm{N}(\%)\end{array}$} & \multirow{2}{*}{$\begin{array}{c}\begin{array}{c}\text { Healthy } \\
\text { people } \\
(\mathrm{n}=13)\end{array} \\
\mathrm{N}(\%)\end{array}$} & \multirow{2}{*}{$\begin{array}{c}\text { OR } \\
95 \% \mathrm{CI} \\
\text { P-value }\end{array}$} & \multirow{2}{*}{$\begin{array}{c}\begin{array}{c}\text { Chronic } \\
\text { gastritis } \\
(\mathrm{n}=5)\end{array} \\
\mathrm{N}(\%)\end{array}$} & \multirow{2}{*}{$\begin{array}{l}\text { Peptic ulcer } \\
\qquad(\mathrm{n}=17) \\
\mathrm{N}(\%)\end{array}$} & \multirow{2}{*}{$\begin{array}{c}\text { Gastric cancer } \\
\qquad \begin{array}{c}(\mathrm{n}=2) \\
\mathrm{N}(\%)\end{array}\end{array}$} & & \\
\hline & & & & & & & & Patients & $\begin{array}{c}\text { Healthy } \\
\text { people }\end{array}$ \\
\hline \multirow[t]{3}{*}{ Genotype } & TT & $7(29.2)$ & $2(15.4)$ & $\begin{array}{c}2.26 \\
0.39-12.9 \\
P=0.36\end{array}$ & $1(20)$ & $4(23.4)$ & $2(100)$ & 58 & \multirow{5}{*}{31.1} \\
\hline & GG & $5(20.8)$ & $6(46.2)$ & $\begin{array}{c}0.3 \\
0.07-6.3 \\
\mathrm{P}=0.115\end{array}$ & $0(0)$ & $5(29.4)$ & $0(0)$ & 52 & \\
\hline & TG & $12(50)$ & $5(38.5)$ & $\begin{array}{c}1.6 \\
0.4-6.3 \\
\mathrm{P}=0.5\end{array}$ & $4(80)$ & $8(47.1)$ & $0(0)$ & 49.1 & \\
\hline \multirow[t]{2}{*}{ Allele } & $\mathbf{T}$ & $26(54.2)$ & $9(34.5)$ & $\begin{array}{c}2.23 \\
0.83-5.99 \\
\mathrm{P}=0.11\end{array}$ & - & - & - & & \\
\hline & $\mathrm{G}$ & $22(45.8)$ & $17(65.4)$ & $\begin{array}{c}0.45 \\
0.17-1.2 \\
P=0.11\end{array}$ & - & - & - & & \\
\hline
\end{tabular}


Table 5. Alleles and genotypes frequencies of $I L-2-330 \mathrm{~T}>\mathrm{G}$ and serum level of $\mathrm{IL}-2$ in the $H$. pylori-positive patients and healthy people.

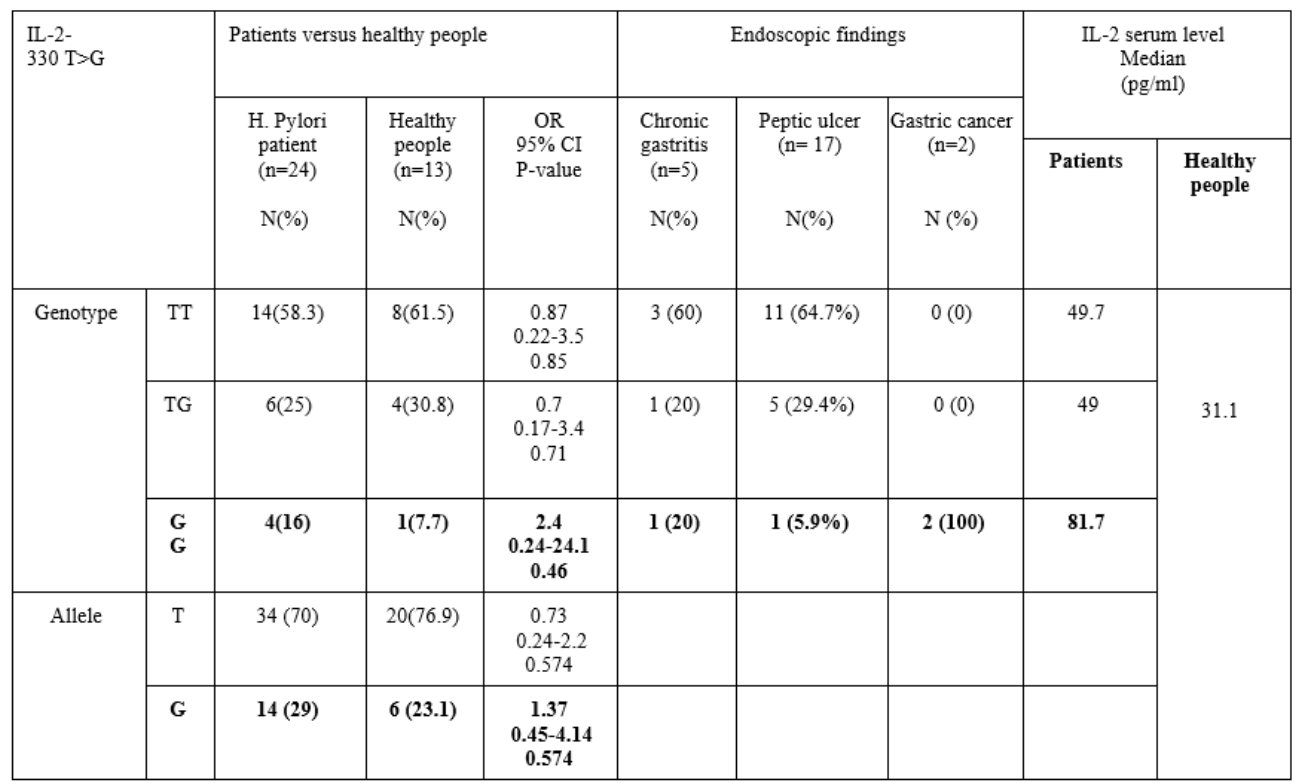

In this study, we detected a high frequency of IL-6-174 and -572 SNPs in patients with gastroduodenal disease associated with $\mathrm{H}$. pylori. We found that gastric cancer was associated with GG genotype of -174 and GC genotype of -572 SNP which are like other studies [7], [20]. On other hand, the GG genotype in both SNPs was more frequent among people who have a peptic ulcer or chronic gastritis. These results agree with those found by Gatti et al. 2007 [7]. Furthermore, we investigated the polymorphisms of IL-6 gene -572 and -174 SNPs about their serum levels. We found high serum levels associated with IL-6-174 G/G (169 pg/ml) and -572 $\mathrm{G} / \mathrm{C}(181 \mathrm{pg} / \mathrm{ml})$ genotypes, both genotypes detected in cancer patients. Chae et al. (2016) found that IL6-174 polymorphisms affect IL-6 expression in G allele carriers and are linked with greater plasma concentrations [16]. The connection between interleukin-6 polymorphisms and serum levels has been studied in several research [21]. The GG genotype gene was discovered to be responsible for manufacturing more IL-6 than the IL-6 -572 GC genotype [22]. Mucosal injury is caused by the insusceptible activity and assimilated immunity in gastro-duodenal disease caused by H. pylori. CD4 cells release a variety of cytokines that are involved in pathophysiology in which the disease had been found to cause inflammation of the gastroduodenal disease-associated H. pylori [23]. By affecting the transcriptional control of the IL-6 gene, IL-6 gene polymorphisms may affect inter-individual variability in blood levels of IL-6 expression [24]. According to Barisani et al. (2006), polymorphism at locations -174 and -572 influences IL-6 expression [25]. Overall, the present findings demonstrate the odds of developing H. pylori infections (gastritis, peptic ulcer, and gastric ulcer) were highest in those people with high producer polymorphism (GG genotype) while that the low production of IL-6 (CC genotype) seemingly provides some protection against the susceptibly and development of H. pylori infections. 
Furthermore, as compared to healthy people, the prevalence of IL- $2+114$ TT genotype, T allele, and IL-2 -330 GG genotype, G allele is significantly greater in $\mathrm{H}$. pylori-infected patients. In these patients, these SNPs could be taken for the growth of gastroduodenal illness. Also, the present data showed that $+114 \mathrm{GG}$ genotype, $\mathrm{G}$ allele, and $-330 \mathrm{TG}$ genotype, $\mathrm{T}$ allele could be protective against the susceptibly and development of $\mathrm{H}$. pylori infections. These findings corresponded with those in another research [26]. However, a bigger sample size is required to corroborate the findings.

The present results showed high levels of IL 2 in serum associated with IL-2 -330 SNP GG genotype $(81.7 \mathrm{pg} / \mathrm{ml})$ and with $+114 \mathrm{TT}$ genotype $(58 \mathrm{pg} / \mathrm{ml})$. Many studies considered that having the IL-2-330 GG and 114 TT genotype increases the risk of a variety of illnesses, including B-Cell Non-Hodgkin Lymphoma [27] and Gastric cancer [28, 29]. Changes in gene promoter activity usually cause changes in gene expression levels, and the IL-2 gene that is clarified by its impact on cytokine [30].

Overall, the current data imply that genetic variants in the IL-6 and IL-2 genes are biologically relevant in the development of H. pylori-induced gastro-duodenal illness. The influence of ILs gene polymorphism on cytokine expression elucidates the biological relevance of ILs gene polymorphism. The study's biggest limitation was the small number of patients, most of whom had stomach cancer. However, many samples is required for additional research to confirm the link between IL-6 and IL-2. More understanding of such association would be of importance in determining the clinical implications of these genetic variations about $\mathrm{H}$. pylori-induced gastroduodenal disorders.

\section{References}

1. Owen, J. Punt, J. and Stranford, S. Kuby Immunology.7th edition. New York : W.H. Freeman; 2013:116- 118 .

2. Sugimoto, M.Yamaoka, Y. and Furuta, T.. Influence of interleukin polymorphisms on development of gastric cancer and peptic ulcer. World J Gastroenterol. 2010; 16(10): 11881200 .

3. Rudnicka K, Backert S, Chmiela M. Genetic Polymorphisms in Inflammatory and Other Regulators in Gastric Cancer: Risks and Clinical Consequences. Curr Top Microbiol Immunol. 2019;421: 53-76.

4. Song H, Chen L, Cha Z, Bai J. Interleukin 2 gene polymorphisms are associated with nonHodgkin lymphoma. DNA Cell Biol. 2012;31(7):1279-1284.

5. Hein TM, Sander P, Giryes A, Reinhardt JO, Hoegel J, Schneider EM. Cytokine Expression Patterns and Single Nucleotide Polymorphisms (SNPs) in Patients with Chronic Borreliosis. Antibiotics (Basel). 2019;8(3):107.

6. Luo Y, Zheng SG. Hall of Fame among Pro-inflammatory Cytokines: Interleukin-6 Gene and Its Transcriptional Regulation Mechanisms. Front Immunol. 2016;7:604.

7. Gatti LL, Burbano RR, Zambaldi-Tunes M, de-Lábio RW, de Assumpção PP, de Arruda Cardoso-Smith M, Marques-Payão SL. Interleukin-6 polymorphisms, Helicobacter pylori 
infection in adult Brazilian patients with chronic gastritis and gastric adenocarcinoma. Arch Med Res. 2007;38(5):551-5.

8. Chakravorty, M. de Datta,D Choudhury, A. et al. Association of specific haplotype of TNF with $\alpha$ Helicobacter pylori-mediated duodenal ulcer in eastern Indian population. J Genet. 2008; 87:299-304.

9. Hwang IR, Hsu PI, Peterson LE, Gutierrez O, Kim JG, Graham DY, Yamaoka Y. Interleukin6 genetic polymorphisms are not related to Helicobacter pylori-associated gastroduodenal diseases. Helicobacter. 2003;8(2):142-8.

10. Zhang WG, Bai XJ, Chen DP, Lv Y, Sun XF, Cai GY, Bai XY, Chen XM. Association of Klotho and interleukin 6 gene polymorphisms with aging in Han Chinese population. J Nutr Health Aging. 2014;18(10):900-4.

11. Hall TA. BioEdit: a user-friendly biological sequence alignment editor and analysis program for Windows 95/98/NT. Nucl Acids Symp Ser. 1999;41:95-98.

12. Matos MF, Lourenço DM, Orikaza CM, Bajerl JA, Noguti MA, Morelli VM. The role of IL-6, IL-8 and MCP-1 and their promoter polymorphisms IL-6 -174GC, IL-8 -251AT and MCP$1-2518 \mathrm{AG}$ in the risk of venous thromboembolism: a case-control study. Thromb Res. 2011;128(3):216-20.

13. Fishman D, Faulds G, Jeffery R, Mohamed-Ali V, Yudkin JS, Humphries S, Woo P. The effect of novel polymorphisms in the interleukin-6 (IL-6) gene on IL-6 transcription and plasma IL-6 levels, and an association with systemic-onset juvenile chronic arthritis. J Clin Invest. 1998 Oct 1;102(7):1369-76.

14. Kai H, Kitadai Y, Kodama M, Cho S, Kuroda T, Ito M, Tanaka S, Ohmoto Y, Chayama K. Involvement of proinflammatory cytokines IL-1beta and IL-6 in progression of human gastric carcinoma. Anticancer Res. 2005;25(2A):709-13.

15. Ashizawa T, Okada R, Suzuki Y, Takagi M, Yamazaki T, Sumi T, Aoki T, Ohnuma S, Aoki T. Clinical significance of interleukin-6 (IL-6) in the spread of gastric cancer: role of IL-6 as a prognostic factor. Gastric Cancer. 2005;8(2):124-31.

16. Chae JW, Ng T, Yeo HL, Shwe M, Gan YX, Ho HK, Chan A. Impact of TNF- $\alpha$ (rs1800629) and IL-6 (rs1800795) Polymorphisms on Cognitive Impairment in Asian Breast Cancer Patients. PLoS One. 2016;11(10):e0164204.

17. Bashashati M, Moradi M, Sarosiek I. Interleukin-6 in irritable bowel syndrome: A systematic review and meta-analysis of IL-6 (-G174C) and circulating IL-6 levels. Cytokine. 2017; 99:132-138.

18. Chen J, Liu RY, Yang L, Zhao J, Zhao X, Lu D, Yi N, Han B, Chen XF, Zhang K, He J, Lei Z, Zhou Y, Pasche B, Li X, Zhang HT. A two-SNP IL-6 promoter haplotype is associated with increased lung cancer risk. J Cancer Res Clin Oncol. 2013;139(2):231-42. 
19. Song H, Chen L, Cha Z, Bai J. Interleukin 2 gene polymorphisms are associated with nonHodgkin lymphoma. DNA Cell Biol. 2012 Jul;31(7):1279-84.

20. Kang JM, Kim N, Lee DH, Park JH, Lee MK, Kim JS, Jung HC, Song IS. The effects of genetic polymorphisms of IL-6, IL-8, and IL-10 on Helicobacter pylori-induced gastroduodenal diseases in Korea. J Clin Gastroenterol. 2009;43(5):420-8.

21. Ma Y, Tang RK, Yang X, Peng GG, Liu Y, Wang XM, Wu BH, Yu JM. Lack of an association between interleukin-6 gene promoter polymorphisms $(-174 \mathrm{G} / \mathrm{C},-572 \mathrm{G} / \mathrm{C})$ and ischemic heart disease and/or ischemic stroke: a meta-analysis. Hum Immunol. 2011;72(8):64151 .

22. Jerrard-Dunne P, Sitzer M, Risley P, Buehler A, von Kegler S, Markus HS. Inflammatory gene load is associated with enhanced inflammation and early carotid atherosclerosis in smokers. Stroke. 2004; 35(11):2438-43.

23. Bagheri N, Razavi A, Pourgheysari B, Azadegan-Dehkordi F, Rahimian G, Pirayesh A, Shafigh M, Rafieian-Kopaei M, Fereidani R, Tahmasbi K, Shirzad H. Up-regulated Th17 cell function is associated with increased peptic ulcer disease in Helicobacter pylori-infection. Infect Genet Evol. 2018; 60:117-125.

24. Qi L, van Dam RM, Meigs JB, Manson JE, Hunter D, Hu FB. Genetic variation in IL6 gene and type 2 diabetes: tagging-SNP haplotype analysis in large-scale case-control study and metaanalysis. Hum Mol Genet. 2006;15(11):1914-20.

25. Barisani D, Ceroni S, Meneveri R, Cesana BM, Bardella MT. IL-10 polymorphisms are associated with early-onset celiac disease and severe mucosal damage in patients of Caucasian origin. Genet Med. 2006;8(3):169-74.

26. Abdiev S, Ahn KS, Khadjibaev A, Malikov Y, Bahramov S, Rakhimov B, Sakamoto J, Kodera Y, Nakao A, Hamajima N. Helicobacter pylori infection and cytokine gene polymorphisms in Uzbeks. Nagoya J Med Sci. 2010;72(3-4):167-72.

27. Abdel Rahman HA, Khorshied MM, Reda Khorshid OM, Mourad HM. Association of Interleukin-2-330T/G and Interleukin-10-1082A/G Genetic Polymorphisms with B-Cell NonHodgkin Lymphoma in a Cohort of Egyptians. Turk J Haematol. 2018;35(2):99-108.

28. Melchiades JL, Zabaglia LM, Sallas ML, Orcini WA, Chen E, Smith MAC, Payão SLM, Rasmussen LT. Polymorphisms and haplotypes of the interleukin 2 gene are associated with an increased risk of gastric cancer. The possible involvement of Helicobacter pylori. Cytokine. 2017;96:203-207.

29. Hoffmann SC, Stanley EM, Darrin Cox E, Craighead N, DiMercurio BS, Koziol DE, Harlan DM, Kirk AD, Blair PJ. Association of cytokine polymorphic inheritance and in vitro cytokine production in anti-CD3/CD28-stimulated peripheral blood lymphocytes. Transplantation. 2001;72(8):1444-50. 
30. Świątkowska-Stodulska R, Kitowska A, Skibowska-Bielińska A, Wiśniewski P, Sworczak K. Hageman factor C46T promoter gene polymorphism in patients with hypercortisolism. Horm Metab Res. 2014;46(7):510-4. 